ARTICLE HISTORY: Received: September 05, 2021 Accepted: October 28, 2021 Published: November 04, 2021

УДК 581.541

ТАКСОНОМИЧЕСКИЙ И ЭКОЛОГИЧЕСКИЙ АНАЛИЗ ДРЕВЕСНО-КУСТАРНИКОВОЙ РАСТИТЕЛЬНОСТИ ГОСУДАРСТВЕННОГО НАЦИОНАЛЬНОГО ПРИРОДНОГО ПАРКА «ТАРБАГАТАЙ»

\author{
Садакова Баян Дуйсековна \\ магистрант 2 курса \\ Сапарова Гульнара Сикимбаевна \\ кандидат биологических наук, дочент, \\ Куанышбаева Меруерт Галымовна \\ кандидат биологических наук, доцент, \\ Полевик Василий Владимирович \\ старший преподователь \\ НАО «Университет имени Шакарима города Семей» \\ Казахстан,ВКО, город Семей
}

\title{
TOXONOMIC AND ENVIRONMENTAL ANALYSIS OF WOOD AND SHRUB VEGETATION OF THE STATE NATIONAL NATURAL PARK "TARBAGATAY"
}

\author{
Sadakova Bayan Duisekovna \\ (contact person)-undergraduate NAO "Shakarim University", \\ Semey, Kazakhstan \\ Saparova Gulnara Sikimbaevna \\ -candidate of Biological Sciences-Associate Professor NAO "Shakarim University", \\ Semey, Kazakhstan. \\ Kuanyshbaeva Meruert Galymovna \\ candidate of Biological Sciences-Associate Professor NAO "Shakarim University", \\ Semey, Kazakhstan. \\ Polevik Vasiliy Vladimirovisch \\ senior lecturer NAO "Shakarim University", \\ Semey, Kazakhstan.
}

Аннотация. Целью исследования является определение видового состава дендрофлоры Государственного национального природного парка «Тарбагатай» Урджарского района и определение видовых особенностей. Составление кадастра флоры Государственного национального природного парка «Тарбагатай».

Annotation. The purpose of the study is to determine the species composition of the dendroflora of the State National Natural Park "Tarbagatai" of Urdzhar district and to determine the species features.Compilation of the flora cadastre of the Tarbagatai State National Natural Park.

Ключевые слова: Тарбагатай, дендрофлора, древесная растительность, кустарник, склон

Keywords: Tarbagatai, dendroflora, woody vegetation, shrub, slope.

Государственный национальный природный парк «Тарбагатай» организован в 2018 году 27 июня Постановлением Правительства Республики Казахстан № 382. Общая площадь национального природного парка (ГНППТ) составляет 143 550,5 га [1].

ГНПП «Тарбагатай» расположен в Урджарском районе Восточно-Казахстанской области.

Территория государственного национального природного парка «Тарбагатай» состоит из шести кластерных участков:

1. Участок «Горы Тарбагатай» (117 384,1 га),

2. Участок «Горы Карабас» $(8475,2$ га),

3. Участок «Горы Аркалы» (15 634,2 га),

4. Участок «Долина р. Уржар» (447 га),

5. Участок «Долина р. Катынсу» (960 га),

6. Участок «Долина р. Емель» (650 га) [2].

Территория национального природного парка-это уникальные природные комплексы и объекты Государственного природно-заповедного фонда (ГПЗФ). Относится ко второй категории особо охраняемых 
природных территорий со статусом природоохранного и научного учреждения Республиканского значения, предназначена для сохранения биологического и ландшафтного разнообразия, имеющая особую экологическую, научную историко-культурную и рекреационную ценность [1].

Флора хребта Тарбагатай насчитывает на сегодняшний день около 1640 видов растений, что говорит о ее значительном видовом богатстве с учетом относительно небольшой высоты Тарбагатая, что обуславливает отсутствие лесного и нивального поясов растительности [2].

Растения исследуемой территории принадлежат к 80 семействам и 504 родам, среди которых отмечено 14 видов папоротникообразных $(0,9 \%), 4$ вида хвощевых $(0,2 \%), 6$ видов голосеменных $(0,4 \%), 334$ вида однодольных (20,5\%) и 1269 видов двудольных (78\%) [2].

Во флоре Тарбагатая преобладают сложноцветные (Asteraceae), злаки (Poaceae), бобовые (Fabaceae), крестоцветные (Brassicaceae) и розоцветные (Rosaceae). Из числа родов, представленных в Тарбагатае, наибольшее количество видов имеет род Astragalus, затем Carex, далее - Artemisia. Из общего количества родов только 24 (около 5\%) имеют в своем составе 10 и более видов растений [2].

Господствующей жизненной формой являются травянистые многолетники - 75,6\% флоры. Однолетние и двулетние травы составляют 15,3\%. Деревья представлены всего 21 видом (1,3\%), кустарники- 69 видами $(4,2 \%)$, кустарнички и полукустарнички - 45 видами $(2,7 \%)[2]$.

Древесная растительность изучаемой территории выражается смешанными лиственными лесами и подлесками, которые произрастают в долинах рек и в предгорьях и среднегорье хребта Тарбагатай [3].

На территории государственного национального природного парка «Тарбагатай» «Лесоустроительные» работы не проводились, дающие достоверные сведения о количестве, площади фактического лесного фонда, распространенного на территории. Работы по «Лесоустройству» запланированы на 2022-2023 годы. Основные сведения, используемые в научно-исследовательской работе, получены на основании таксационных записей 2005 года, проведенных «Тау-далинским» филиалом Государственного природного резервата «Семей орманы» ВКО в кварталах 1-39 Урджарского лесничества.

В качестве материалов исследовательской работы рассматривается видовой состав дендрофлоры государственного национального природного парка «Тарбагатай».

Новизной исследовательской работы будет проведение таксономического и экологического анализов видового состава дендрофлоры исследуемого региона и составление кадастра.

Древесная растительность предствлена 21 видом произростающих в естественном бионте плюс 4 вида инвазивнораспостраненных вследствие хозяйственной деятельности населения. Из 21 видов деревьев: 11 видов относятся к семейству Ивовые (52\%), 5 к семейству Березовые (23\%), 4 к семейству Розоцветные (19\%) и 1вид к семейству Адоксовые (4\%) (рис 1).

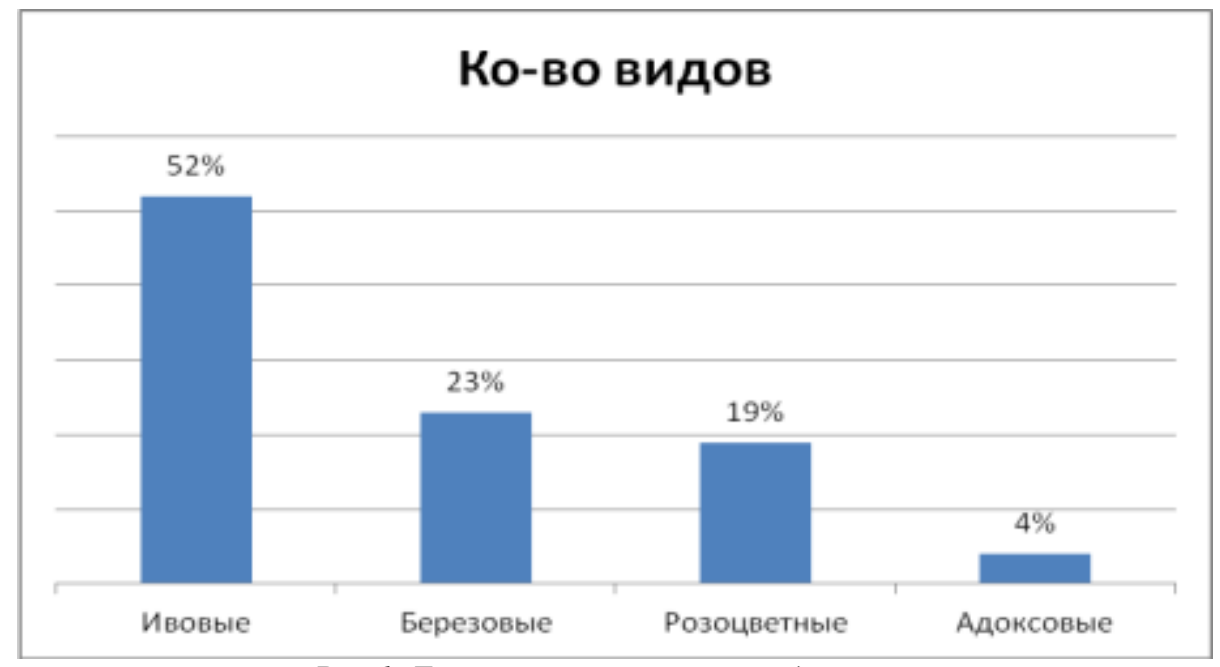

Рис 1. Таксономический состав деревьев

Инвазивные виды представлены: 2 вида семейства Кленовые, 1 вид семейства Ильмовые и 1 вид семейства Лоховые. Инвазивные виды в настоящее время преобладают в долинах рек и происходит вытеснение естественных видов, например число видов семейства Ивовых и Березовых заметно сократилось. Это одна из причин сокращения видов, другая причина не контралируемый выпас скота, увелечение числа скота и пастбищ, незаконная рубка леса.

По сведениям ТОО центр дистанционного зондирования и ГИС «ТЕРРА» защитивших Проект естественнонаучного обоснования создания Тарбагатайского государственного национального природного парка, на 
территории встречается 69 вида кустарника, что составляет $(4,2 \%)$ от общего числа видов флоры. Разнообразие кустарниковой растительности связано с преобладанием кустарникового и степного поясов, принадлежность к различным экологическим группам определяет большое разнообразие их ассоциаций (таб.1). Большей частью в зарослях доминирует один из видов кустарников, реже встречаются полидоминантные кустарниковые сообщества, в сложении ценоза которых одновременно участвует несколько видов кустарников.

Таблица 1

Таксономический состав кустаринков

\begin{tabular}{|c|c|c|c|}
\hline \multirow{2}{*}{ Семейство } & \multicolumn{2}{|c|}{ Число } & \multirow{2}{*}{ Доля из общего числа, } \\
& Родов & Видов & $4,3 \%$ \\
\cline { 2 - 3 } & 1 & 3 & $16 \%$ \\
\hline Кипарисовые & 1 & 11 & $7,2 \%$ \\
\hline Ивовые & 1 & 5 & $2,9 \%$ \\
\hline Гречишные & 2 & 2 & $4,3 \%$ \\
\hline Маревые & 1 & 3 & $10,1 \%$ \\
\hline Барбарисовые & 2 & 7 & $34,8 \%$ \\
\hline Камнеломковые & 8 & 24 & $11,6 \%$ \\
\hline Розоцветные & 3 & 8 & $2,9 \%$ \\
\hline Бобовые & 1 & 2 & $2,9 \%$ \\
\hline Крушиновые & 2 & 2 & $1,4 \%$ \\
\hline Гребенщиковые & 1 & 1 & $1,4 \%$ \\
\hline Волчниковые & 1 & 1 & $7,2 \%$ \\
\hline Лоховые & 2 & 5 & \\
\hline Жимолостные & & & \\
\hline
\end{tabular}

\section{Доля из общего числа, \%}

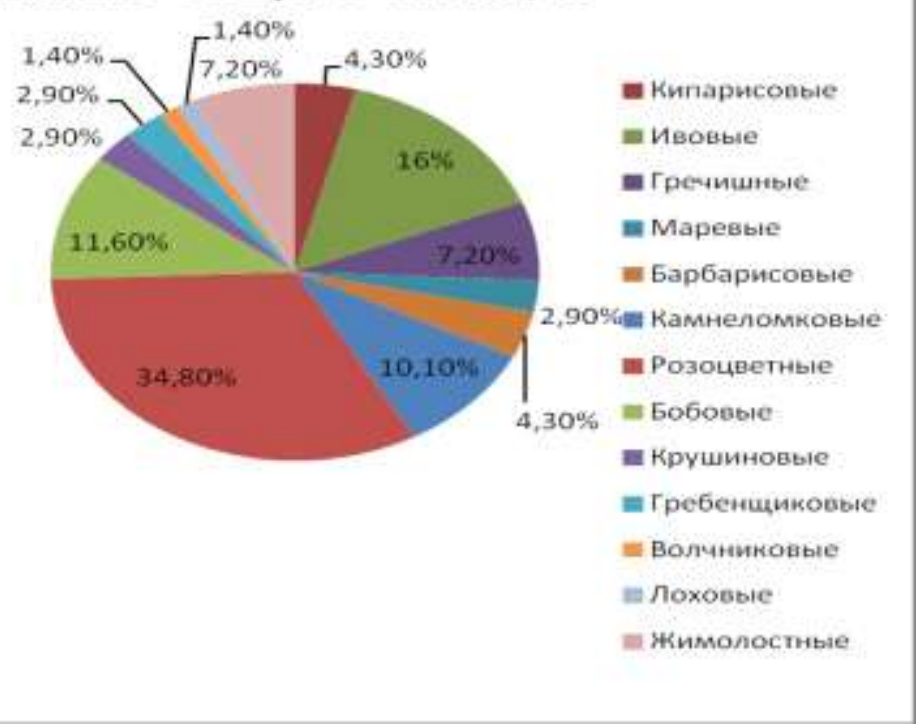

Рис. 2 Таксономический состав кустарников

На территории парка установлены фенологические и мониторинговые площадки, проведены экспериментальные мониторингово-фенологические наблюдения за фазами роста древесных растений. С целью определения видового состава денрофлоры с мая по август на территорию парка мы выезжали в экспедиции, в ходе которых были собраны гербарные материалы. При исследовательской работе использовались общепринятые методы полевых ботанических исследований и методы инвентаризации лесного фонда [4]. В соответствии с установленными нормативами точности применялись следующие методы: глазомерноизмерительный, глазомерный. В период полевых экспедиций на территорию национального парка в целях определения видового состава дендрофлоры сначало глазомерно, то есть визуально, определялся ареал произрастания древесных растений, после определялся видовой состав. Древесная растительность каждого кластерного участка отличается друг от друга, поэтому в целях изучения и ведения фенологических наблюдений были установлены фенологические и мониторинговые площадки. 
Использовался метод пробных площадок для определения травянного покрова и вида формаций. Ведется учет флористического состава по Друде. После окончания полевого периода проводится работа по анализу и систематизации флоры в результате выявления и камеральной обработки гербарных материалов (рис 3).

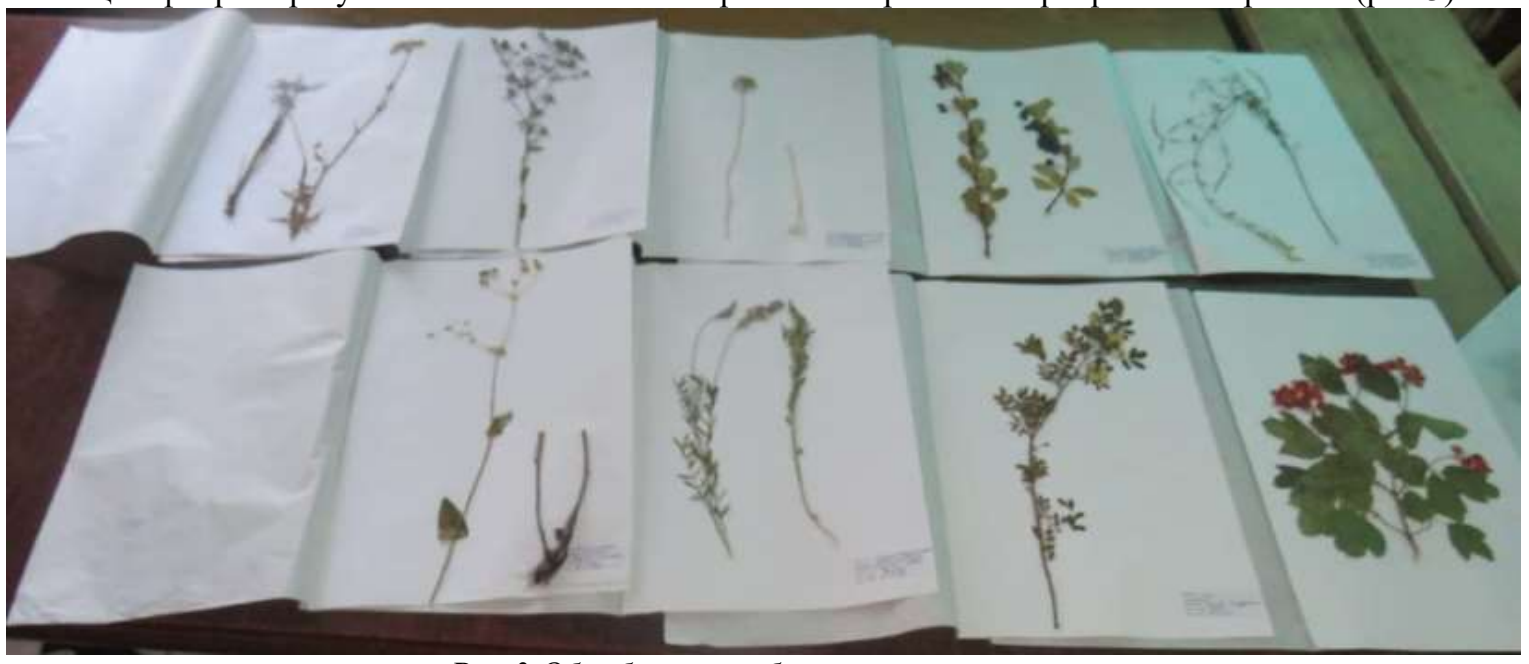

Рис.3 Обработка гербарных материалов

Список древесных и кустарниковых растений произрастающих на территории национального природного парка «Тарбагатай»:

\begin{tabular}{|c|c|c|c|}
\hline Смейство & Род & Вид & Жизненная форма \\
\hline \multirow{3}{*}{$\begin{array}{l}\text { 1.Cupressaceae- } \\
\text { Кипарисовые }\end{array}$} & \multirow{3}{*}{$\begin{array}{c}\text { Juníperus- } \\
\text { Можжевельник }\end{array}$} & $\begin{array}{l}\text { 1.Juniperus sibirica- } \\
\text { Можжевельник сибирский }\end{array}$ & $\begin{array}{c}\text { Кустарник, ксерофит, } \\
\text { субальпийский пояс гор } \\
\text { Тарбагатай сор. } \\
\end{array}$ \\
\hline & & $\begin{array}{l}\text { 2. Juníperus sabina- } \\
\text { Можжевельник казацкий }\end{array}$ & $\begin{array}{c}\text { Кустарник, ксерофит, степной } \\
\text { пояс юж. и сев. склонов гор } \\
\text { Тарбагатай сор. }\end{array}$ \\
\hline & & $\begin{array}{l}\text { 3. Juniperus pseudosabina- } \\
\text { Можжевельник ложноказацкий }\end{array}$ & $\begin{array}{c}\text { Кустарник, ксерофит, } \\
\text { субальпийский и альпийский } \\
\text { пояса гор Тарбагатай сор. }\end{array}$ \\
\hline \multirow{4}{*}{$\begin{array}{l}\text { 2.Salicaceae Mirb.- } \\
\text { Ивовые }\end{array}$} & 1. Salix-Ива & Salix caprea L.- Ива козья & $\begin{array}{c}\text { Дерево, мезофит, по берегам рек } \\
\text { sp. }\end{array}$ \\
\hline & \multirow{3}{*}{ 2.Populus-Тополь } & $\begin{array}{c}\text { 1.Populus tremula L.-Осина } \\
\text { обыкновенная }\end{array}$ & $\begin{array}{c}\text { Дерево, мезофит, юж. склон гор } \\
\text { Тарбагатай кустарниковый пояс } \\
\text { сор. } \\
\end{array}$ \\
\hline & & $\begin{array}{c}\text { 2.Populus laurifolia- Тополь } \\
\text { лавролистный }\end{array}$ & $\begin{array}{l}\text { Дерево, мезофит, юж. и сев. } \\
\text { склоны гор Тарбагатай sp. }\end{array}$ \\
\hline & & $\begin{array}{l}\text { 3. Populus danse- Тополь } \\
\text { густолистный }\end{array}$ & $\begin{array}{l}\text { Дерево, мезофит, сев. склоны гор } \\
\text { Тарбагатай sp. }\end{array}$ \\
\hline 3. Betulaceae-Березовые & Betula-Береза & $\begin{array}{c}\text { Betula pendula } \text { Roth.-Береза } \\
\text { повислая }\end{array}$ & $\begin{array}{c}\text { Дерево, мезофит, в долинах рек } \\
\text { sol. }\end{array}$ \\
\hline $\begin{array}{l}\text { 4.Ulmaceae Mirb- } \\
\text { Ильмовые }\end{array}$ & Ulmus- Вяз & Ulmus pumila L- Вяз карликовый & $\begin{array}{c}\text { Дерево, мезофит, в долинах рек } \\
\text { sp. } \\
\text { Инвазивный вид }\end{array}$ \\
\hline $\begin{array}{l}\text { 5.Polygonaceae Lindl.- } \\
\text { Гречишные }\end{array}$ & $\begin{array}{l}\text { Atraphaxis- } \\
\text { Курчавка }\end{array}$ & $\begin{array}{c}\text { Atraphaxis laetevirens- Курчавка } \\
\text { ярко-зеленая }\end{array}$ & $\begin{array}{c}\text { Кустарник, ксерофит, } \\
\text { кустаринковый пояс sp }\end{array}$ \\
\hline $\begin{array}{l}\text { 6.Berberidaceae- } \\
\text { Барбарисовые }\end{array}$ & Berberis- Барбарис & $\begin{array}{c}\text { Berberis heteropoda- Барбарис } \\
\text { разноножковый }\end{array}$ & $\begin{array}{c}\text { Кустарник, ксерофит, юж. склон } \\
\text { гор Тарбагатай кустарниковый } \\
\text { пояс sp. }\end{array}$ \\
\hline $\begin{array}{l}\text { 7.Grossulariaceae- } \\
\text { Крыжовниковые }\end{array}$ & $\begin{array}{l}\text { Grossularia- } \\
\text { Крыжовник }\end{array}$ & $\begin{array}{l}\text { Grossularia acicularis- } \\
\text { Крыжовник игольчатый }\end{array}$ & $\begin{array}{c}\text { Кустарник, ксеропетрофит, } \\
\text { склоны гор Тарбагатай, } \\
\text { кустарниковый и степной пояс } \\
\text { sol. }\end{array}$ \\
\hline 8.Rosaceae Juss.- & 1.Malus-Яблоня & Malus sieversii-Яблоня Сиверса & Дерево, мезофит, центральная \\
\hline
\end{tabular}




\begin{tabular}{|c|c|c|c|}
\hline \multirow[t]{11}{*}{ Розоцветные } & & & $\begin{array}{c}\text { часть юж. склона гор Тарбагатай, } \\
\text { кустарниковый пояс sp. }\end{array}$ \\
\hline & \multirow{2}{*}{$\begin{array}{l}\text { 2.Crataegus- } \\
\text { Боярышник }\end{array}$} & $\begin{array}{l}\text { 1.Crataegus sanguinea- } \\
\text { Боярышник красный }\end{array}$ & Дерево, мезофит, долины рек sol. \\
\hline & & $\begin{array}{c}\text { 2.Crataegus altaica- Боярышник } \\
\text { алтайский }\end{array}$ & $\begin{array}{c}\text { Дерево, мезофит, долины рек, } \\
\text { днища ущелий, степной и } \\
\text { кустариниковый пояс sol. }\end{array}$ \\
\hline & 3. Pádus-Черемуха & $\begin{array}{c}\text { Prúnus pádus- Черемуха } \\
\text { обыкновенная }\end{array}$ & $\begin{array}{l}\text { Дерево, мезофит, поймы рек, } \\
\text { степной и кустарниковый пояс } \\
\text { sol. }\end{array}$ \\
\hline & \multirow{5}{*}{ 4.Rosa-Шиповник } & $\begin{array}{c}\text { 1.Rosa spinosissima- Шиповник } \\
\text { колючащий }\end{array}$ & $\begin{array}{c}\text { Кустарник, мезофит, степной и } \\
\text { кустарниковый пояс soc. }\end{array}$ \\
\hline & & $\begin{array}{c}\text { 2.Rosa laxa Retz. Шиповник } \\
\text { рыхлый }\end{array}$ & $\begin{array}{c}\text { Кустарник, мезофит, степной и } \\
\text { кустарниковый пояс sp. }\end{array}$ \\
\hline & & $\begin{array}{c}\text { 3.Rosa alberti Rgl. Шиповник } \\
\text { Альберта } \\
\end{array}$ & $\begin{array}{c}\text { Кустарник, мезофит, степной и } \\
\text { кустарниковый пояс sp. }\end{array}$ \\
\hline & & $\begin{array}{c}\text { 4.Rosa platyacantha Шиповник } \\
\text { плоскошипый }\end{array}$ & $\begin{array}{c}\text { Кустарник, мезофит, степной и } \\
\text { кустарниковый пояс sol. }\end{array}$ \\
\hline & & $\begin{array}{c}\text { Hulthemia berberifolia- Гультемия } \\
\text { барбарисолистная }\end{array}$ & $\begin{array}{l}\text { Кустарник, ксерофит, пустынные } \\
\text { степи sp. }\end{array}$ \\
\hline & \multirow{2}{*}{$\begin{array}{l}\text { 5. Cotoneaster- } \\
\text { Кизильник }\end{array}$} & $\begin{array}{c}\text { 1.Cotoneaster uniflora Кизильник } \\
\text { одноцветковый }\end{array}$ & $\begin{array}{c}\text { Кустарник, ксеропетрофит, } \\
\text { альпийский и субальпийский } \\
\text { пояс sol. }\end{array}$ \\
\hline & & $\begin{array}{l}\text { 2.Cotoneaster multiflora- Bge. } \\
\text { Кизильник многоцветковый }\end{array}$ & $\begin{array}{c}\text { Кустарник, ксерофит, } \\
\text { кустаринковый пояс sol. }\end{array}$ \\
\hline & $\begin{array}{l}\text { 6.Amygdalus- } \\
\text { Миндаль }\end{array}$ & $\begin{array}{c}\text { Amygdalus ledebouriana-Миндаль } \\
\text { Ледебура }\end{array}$ & $\begin{array}{c}\text { Кустарник, ксерофит, степной и } \\
\text { кустаринковый пояс soc. }\end{array}$ \\
\hline 9.Leguminosae-Бобовые & Caragana- Карагана & $\begin{array}{c}\text { Caragana frutex-Карагана } \\
\text { кустарниковая }\end{array}$ & $\begin{array}{c}\text { Кустарник, мезофит, степной и } \\
\text { кустаринковый пояс sp. }\end{array}$ \\
\hline $\begin{array}{l}\text { 10.Rhamnáceae- } \\
\text { Крушиновые }\end{array}$ & Frangula- Крушина & Frangula alnus Крушина ломкая & $\begin{array}{c}\text { Кустарник, ксерофит, } \\
\text { кустаринковый пояс sol. }\end{array}$ \\
\hline $\begin{array}{l}\text { 11.Thymelaeaceae Juss.- } \\
\text { Волчниковые }\end{array}$ & $\begin{array}{c}\text { Daphne- } \\
\text { Волчеягодник }\end{array}$ & $\begin{array}{c}\text { Daphne altaica- Волчеягодник } \\
\text { алтайский }\end{array}$ & $\begin{array}{c}\text { Кустарник, ксерофит, } \\
\text { кустарниковый и в нижней части } \\
\text { субальпийского поясов sol. }\end{array}$ \\
\hline \multirow{2}{*}{$\begin{array}{l}\text { 12.AceraceaeJuss.- } \\
\text { Кленовые }\end{array}$} & \multirow[b]{2}{*}{ Ácer- Клен } & $\begin{array}{l}\text { 1.Ácer negúndo Клен } \\
\text { ясенелистный }\end{array}$ & $\begin{array}{l}\text { Дерево, мезофит, степной пояс, в } \\
\text { долинах рек sp. Инвазивный вид }\end{array}$ \\
\hline & & 2.Acer semenovii Клен Семенова & $\begin{array}{c}\text { Дерево, мезофит, степной и } \\
\text { кустарниковый пояс, в долинах } \\
\text { рек sp. } \\
\text { Инвазивный вид }\end{array}$ \\
\hline $\begin{array}{l}\text { 13.Elaeagnaceae Juss.- } \\
\text { Лоховые }\end{array}$ & Elaeagnus- Лox & $\begin{array}{c}\text { Elaeagnus oxycarpa Лох } \\
\text { остроплодный }\end{array}$ & $\begin{array}{c}\text { Дерево, мезофит, степной пояс и } \\
\text { пустынные степи sp. } \\
\text { Инвазивный вид }\end{array}$ \\
\hline $\begin{array}{l}\text { 14.Caprifoliaceae- } \\
\text { Жимолостные }\end{array}$ & $\begin{array}{c}\text { Lonicera- } \\
\text { Жимолость }\end{array}$ & $\begin{array}{c}\text { Lonicera tatarica- Жимолость } \\
\text { татарская }\end{array}$ & $\begin{array}{c}\text { Кустарник, мезофит, степной и } \\
\text { кустаринковый пояс sp. }\end{array}$ \\
\hline $\begin{array}{l}\text { 15.Adoxaceae } \\
\text { Адоксовые }\end{array}$ & Vibúrnum- Калина & $\begin{array}{c}\text { Vibúrnum ópulus Калина } \\
\text { обыкновенная }\end{array}$ & $\begin{array}{l}\text { Кустарник, мезофит, степной и } \\
\text { кустаринковый пояс sp. }\end{array}$ \\
\hline
\end{tabular}

Среди древесных и кустарниковых растений национального парка есть виды, которые являются доминантами и субдоминантами растительных сообществ. Среди деревьев это 4 вида, яблоня Сиверса Malus sieversii, осина обыкновенная Populus tremula L., тополь лавролистный Populus laurifolia, ива козья Salix caprea L., среди кустарников 8 видов, это шиповник колючейший Rosa spinosissima, шиповник иглистый Rosa acicularis, миндаль Ледебура Amygdalus ledebouriana, курчавка ярко-зеленая Atraphaxis laetevirens, кизильник одноцветковый Cotoneaster uniflora, карагана кустарниковая Caragana frutex, барбарис разноножковый Berberis heteropoda, можжевельник сибирский Juniperus sibirica.

В единой цепи сохранения биоразнообразия любого региона важнейшее место занимают редкие и уникальные растения. В национальном парке «Тарбагатай» произростают 35 видов высших сосудистых 


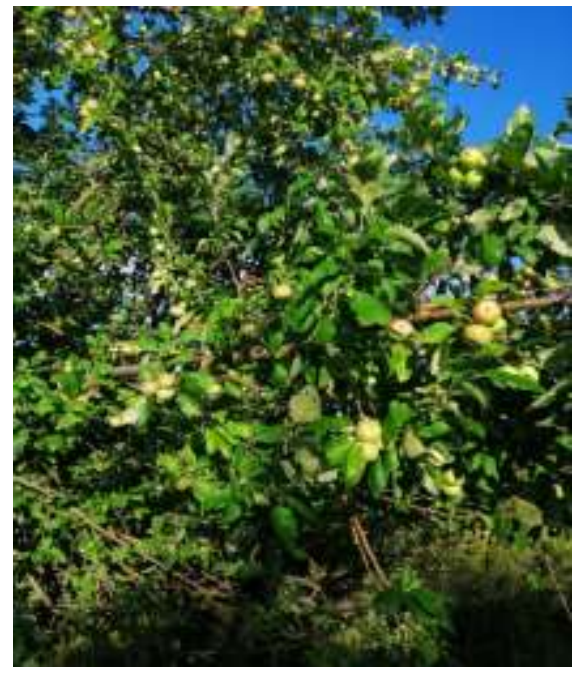

растений занесенных в Красную книгу Казахстана, что состовляет 2,1\% от флоры. Остановимся на краснокнижных представителях денрофлоры:

1. Яблоня Сиверса Malus sieversii- дерево от 2 до 10 (14) м высоты с желтыми кисло-сладкими плодами, диаметром 3-4 см. В Тарбагатае яблоня Сиверса образует насаждения с сомкнутостью древесного полога 0,2-0,6 (0,8) или единично разбросана среди кустарниковой растительности. Из всех яблонь яблоня Сиверса (Malus sieversii) по качеству плодов наиболее близка к культурным формам. Благодаря сравнительной крупноплодности и хорошим вкусовым качествам она представляет большой хозяйственный интерес. По своему происхождению яблоня Сиверса несомненно связана с третичными мезофильными лесами. Являясь реликтом этих лесов, она до некоторой степени проясняет историю растительности хребта Тарбагатай.

\section{2. Миндаль Ледебура Amygdalus ledebouriana-} Ветвистый листопадный кустарник высотой до 1,5 м. Листья очерёдные, простые, линейно-ланцетные или широко-эллиптические, тёмнозелёного цвета. Цветки крупные ярко-розовые; цветёт ранней весной, одновременно с распусканием листьев. Плод - войлочно-мохнатая костянка со сжатой косточкой. Растет в степном и кустарниковом поясах центральной части южного склона хребта, образуя заросли.

3. Сибирка Алтайская Sibiraea altaiensis- Листопадный двудомный кустарник 0,6-1,5 м высоты. Крона до 2,5 м диаметром, густая, широко раскидистая. Ветви прямостоячие, раскидистые и распростертые, красные или

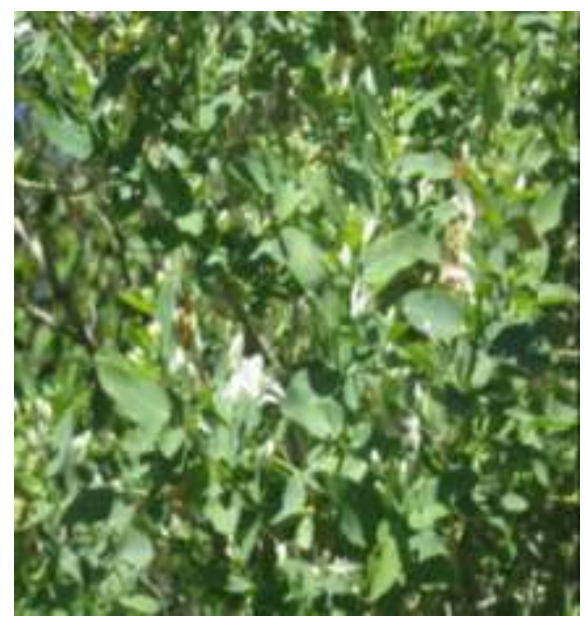
пурпурно-коричневые, гладкие. Листья 5-11 см длины и 2 см ширины, обратноланцетные или продолговатые, к основанию суженные в короткий крылатый черешок или сидячие, с коротко заостренной верхушкой. На верхушке часто с очень коротким и тонким шипиком, цельнокрайние, плотные, голые, голубоватозеленые, похожие на листья молочая, осенью окрашивающиеся в буровато-оранжевый и красный цвет, долго не опадающие. Соцветия собраны в небольшие метелки из кистей в количестве до 10 штук, они расположены на длинных боковых побегах. Метёлки с белыми цветами скрыты в пазухах листьев, сужающихся кверху. Мужские метелки до 12 см длины, более крупные и рыхлые, чем женские. Цветет в июне. Плодоносит в июле-августе. Цветочки белого цвета также собранные в метелки. Период цветения может быть разной продолжительности, максимально 25 дней с первой декады летнего сезона.

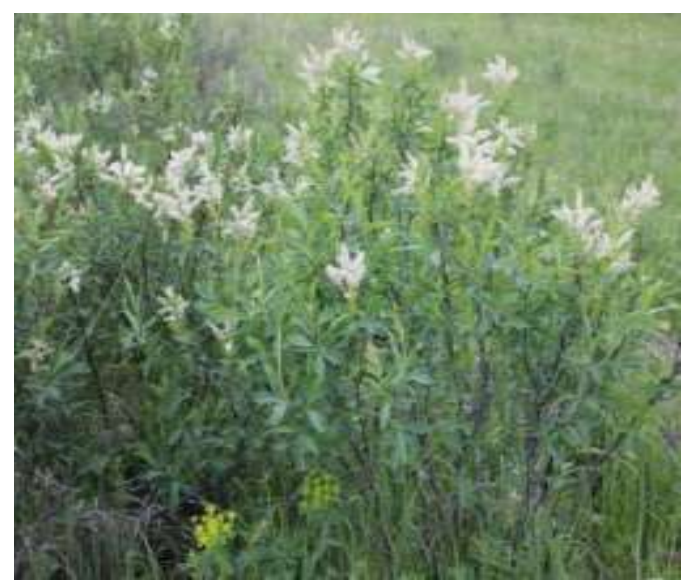

Цветки однополые, с приятным ароматом, характеризуются также выделением нектара, который доступен многим короткохоботковым насекомым.Морозостоек до минус 45С. Встречается очень редко в кустарниковом поясе хребта Тарбагатай.

4. Волчеягодник алтайский Daphne altaica- Реликт. Корнеотпрысковый листопадный кустарник высотой $1-1,5$ м. Молодые ветви опушены, старые голые. Листья ланцетные, эллиптические или овальные, 2,5-6 см длиной и 7-15 мм шириной, сужены в короткий черешок, сверху зеленые, снизу сизоватые. Околоцветник белого цвета, гвоздевидный. Плод костянка буро-черного цвета, ядовитый. Цветет в мае, начале июня, плодоносит в июне, июле. В Тарбагатае растет в кустарниковом и нижней части субальпийского поясов в зарослях кустарников. 
Кроме перечисленных выше редких и поистене униальных для данной территории видов, следует назвать еще эндемичные виды для Тарбагатая. Флора Тарбагатая содержит 169 эндемичных видов, среди них выделяются собственно тарбагатайские эндемы, составляющие 25 видов, или 1,5\% от флоры Тарбагатая. Они приурочены к различным родам и семействам и довольно разнообразны: Calophaca howenii, Mertensia tarbagataica, Mertensia popovii, Stelleropsis Tarbagataica, Acantholimon tarbagataicum, Scutellaria irrregularis, Artemisia perctinata и др.

Древесная растительность национального парка «Тарбагатай» не очень обширна, она разбросана по хребту Тарбагатай и в долинах рек Емель, Урджар, Катынсу на небольших участках. Подводя итог выше изложенного, можно объединить представителей дендрофлоры исследуемой территории в несколько групп:

1. Пищевые растения-Malus sieversii Яблоня Сиверса, Crataegus sanguinea Боярышник красный, Crataegus altaica Боярышник алтайский, Prúnus pádus Черемуха обыкновенная, Berberis heteropoda Барбарис разноножковый, Grossularia acicularis Крыжовник игольчатый.

2. Витаминные растения-Rosa spinosissima Шиповник колючащий, Rosa laxa Retz. Шиповник рыхлый, Rosa alberti Rgl. Шиповник Альберта, Cotoneaster uniflora Кизильник одноцветковый, Vibúrnum ópulus Калина обыкновенная, Cotoneaster multiflora Bge. Кизильник многоцветковый, Rosa platyacantha Шиповник плоскошипый.

3. Декоративные растения - Elaeagnus oxycarpa Лох остроплодный, Ácer negúndo Клен ясенелистный, Acer semenovii Клен Семенова, Ulmus pumila L Вяз карликовый, Salix caprea Ива козья, Caragana frutex Карагана кустарниковая.

4. Лекарственные растения- Amygdalus ledebouriana Миндаль Ледебура, Frangula alnus Крушина ломкая, Pópulus trémula Осина обыкновенная, Lonicera tatarica Жимолость татарская, Daphne altaica Bолчеягодник алтайский, Atraphaxis laetevirens Курчавка ярко-зеленая.

\section{Список литературы:}

1. Постановление Правительства Республики Казахстан от 27 июня 2018 года № 382.

2. ТОО центр дистанционного зондирования и ГИС «ТЕРРА» Проект естественно-научное обоснование создания Тарбагатайского государственного национального природного парка// Алматы. 2014. 119 с.

3. Степанова Е.Ф. Растительность и флора хребта Тарбагатай// Алматы. АН Казахской ССР, 1962.450 с.

4. https://www.livemaster.ru/topic/2786055-metodika-polevyh-botanicheskih-issledovanij (дата обращения 10.10.2021).

5. Иващенко А. Цветковые растения юго-востока Казахстана//А.: Ассоциация сохранения биоразнообразия Казахстана, 2008. 182 с.

6. М.С. Байтенов, А.Н. Васильева, А.П. Гамаюнова, В.П. Голоскоков, Н.Х. Кармышева, П. Мырзакулов, А. Оразова, П.П. Поляков, И.И. Ролдугин, Н.Л. Семиотрочева, Н.С. Филатова, В.В. Фисюн, В.Г. Цаголова, В.И. Терехова Иллюстрированный определитель растений Казахстана//Алматы. «Наука». 1969-1972. 1 том-643 с., 2 TOM-570 c.

7. А.Р. Шаймарданова, В.В. Полевик, В.А. Хромов Атлас-Определитель лекарственных растений ВКО//Алматы., Эпиграф 2021., 224c.

8. Н.Ш. Карипбаева, В.В. Полевик, Б.М. Силыбаева Иллюстрированный определитель цветковых растений//Алматы, Эверо, 2019, 247с.

9. Краткий обзор денрофлоры Юго-Западного Тарбагатая (статья)//Материалы международной научнопрактической конференции «Биоразнообразие и устойчивое развитие природы и общества» посвещенной 75 летию КазПУ им.Аль-Фараби и 75-летию биологического факультета. Алматы. «Қазақ университеті» 2009.

\section{References:}

1. Resolution of the Government of the Republic of Kazakhstan dated June 27, 2018 No. 382.

2. Center for Remote Sensing and GIS "TERRA" LLP Project natural-scientific justification for the creation of the Tarbagatai State National Natural Park// Almaty. 2014. 119 p.

3. Stepanova E.F. Vegetation and flora of the Tarbagatai ridge//Almaty. Academy of Sciences of the Kazakh SSR, 1962. $450 \mathrm{p}$.

4. https://www.livemaster.ru/topic/2786055-metodika-polevyh-botanicheskih-issledovanij (10.10.2021).

5. Ivashchenko A. Flowering plants of the South-East of Kazakhstan//Almaty. Association for the Conservation of Biodiversity of Kazakhstan, 2008. 182 p.

6. M.S. Baitenov, A.N. Vasilyeva, A.P. Gamayunova, V.P. Goloskokov, N.H. Karmysheva, P. Myrzakulov, A. Orazova, P.P. Polyakov, I.I. Roldugin, N.L. Semiotrocheva, N.S. Filatova, V.V. Fisyun, V.G. Tsagolova, V.I. Terekhova Illustrated determinant of plants of Kazakhstan// Almaty. "Science". 1969-1972. 1 volume-643 p., 2 volume-570 p.

7. A.R. Shaimardanova, V.V. Polevik, V.A. Khromov Atlas-Determinant of medicinal plants of East Kazakhstan region//Almaty., Epigraph 2021., 224 p.

8. N.Sh. Karipbaeva, V.V. Polevik, B.M. Silybayeva Illustrated determinant of flowering plants//Almaty, Evero, 2019,247 p. 
9. A brief overview of the denroflora of Southwestern Tarbagatai (article)//Materials of the international scientific and practical conference "Biodiversity and sustainable development of nature and society" dedicated to the 75th anniversary of KazPU named after Al//Farabi and the 75th anniversary of the Faculty of Biology. Almaty.: "Kazakh University" 2009 A. 